\title{
INTERNATIONALISATION AND FINANCING OPTIONS OF GHANAIAN SMES
}

\author{
Joshua Abor, University of Ghana Business School - Legon
}

\begin{abstract}
This article presents a study of internationalisation and the financing options of Ghanaian small and medium scale nontraditional exporters. The article also examines how the age and size of an organisation affect the choice of financing. The results show a positive association between debt financing and the age of an organisation. Over time, organisations become more acceptable investments to lenders, and consequently older organisations are more likely to obtain debt financing than their younger counterparts. With respect to size, the results again indicate that larger organisations are more likely to receive debt financing. The results also show a positive relationship between degree of internationalisation and debt financing. The results suggest that as organisations engage more in international activities, they employ more debt but use less of equity financing. This is explained by the fact that organisations involved in international business tend to be more diversified and, as such, are capable of accommodating more debt capital.
\end{abstract}

Keywords: internationalisation, financing, capital structure, SMEs, Ghana

\section{INTRODUCTION}

The problem of financing Ghanaian small and medium scale enterprises (SMEs), especially those in the non-traditional export (NTE) sector, has been of great concern for some time now. This pre-occupation is mainly a result of the role that the SMEs in the NTE sector are supposed to play in the development of the economy. SMEs have been described as the seeds of big businesses and the fuel of national economic engines. Not only are they important for the vitality of the business sector, they also contribute to job creation (Lader, 1996). As a result, governments have undertaken initiatives to promote the growth of SMEs (Feeney \& Riding, 1997). SME development can encourage the process of both inter- and intraregional decentralisation; and, they may well become a countervailing force against the economic power of larger enterprises. More generally, the development of SMEs is seen as accelerating the achievement of wider economic and socio-economic objectives, including poverty alleviation (Cook \& Nixson, 2000). However, an important problem that SMEs often face is access to capital (Lader, 1996). The role of finance has been viewed as a critical element for the development of SMEs (Cook \& Nixson, 2000).

Previous studies have provided various theories regarding the determinants of financial leverage of organisations, such as asset structure, firm size, profitability, risk, and growth (Bradley, Jarrel \& Han Kim, 1984; Harris \& Raviv, 1991; Myers, 1984; Petersen \& Rajan, 1994; Titman \& Wessels, 1988; Wald, 1999). Few empirical studies have validated the theoretical capital structure from an international perspective, and those that have, only focused on the evaluation of the internationalisation effect on identified capital structure determinants to address the difference between large multinational corporations (MNCs) and domestic companies (DCs) (Fatemi, 1988; Lee \& Kwok, 1988; Michel \& Shaked, 1986; Shapiro, 1978). Other researches have focused on the direct effect of international factors, such as political risk, foreign exchange risk, and tax benefits, on the financing policy of MNCs (Burgman, 1996; Lee \& Kwok, 1988).

However, the issue of financing options for SMEs in the internationalisation process has received limited attention. Zingales (2000) asserts that, "empirically, the emphasis on large companies has led us to ignore (or study less than necessary) the rest of the universe: the young and small firms, who do not have access to public markets". 


\section{THE PURPOSE OF THIS ARTICLE}

This article aims to determine the effect of the level of internationalisation on the financing decisions of SMEs NTEs in Ghana. It specifically focuses on the capital structure of small and medium sized exporters drawn from the Ghana Export Promotion Council's (GEPC) database of NTEs in Ghana. To achieve this objective, the article also seeks to incorporate some organisation-level characteristics such as age and size effects, two related variables that have been associated with the capital structure of SMEs. A sample of NTEs in the Greater Accra region was used for the purposes of this article. The structure of the remainder of the article is as follows: a review of the existing literature on the internationalisation of organisations and capital structure theories on SMEs; the methodology employed; the empirical results; and the final conclusion.

\section{LITERATURE REVIEW}

This section provides a review of the theoretical literature on the internationalisation and financing of organisations.

\section{The Internationalisation of Organisations}

Internationalisation of an organisation, from the theoretical stand point, usually tries to give answers to questions about why, when, where, and how organisations engage in international trade. Despite the widespread agreement regarding the growing global integration of economies' activities, there is no general agreement on the definition of internationalisation. Wind, Douglas \& Perlmutter (1973) define this notion as a process in which specific attitudes or orientations are associated with successive stages in the evolution of international operations. Johanson \& Vahlne (1977) conceive internationalisation as a sequential process of increased international involvement, whilst Welch and Luostarinen (1988) interpret internationalisation as the process of increasing involvement in international operations. In a much broader conceptualisation, Calof \& Beamish (1995) interpret internationalisation as the process of adapting an organisation's operations to international environments.

The growing integration of national and regional economies in a global network of production and distribution, together with an increased academic interest in theory development regarding the internationalisation of organisations, lead to the development of a number of new approaches during the post-1970 period. These approaches have been reviewed comprehensively by O'Farrell, Wood \& Zheng (1996) and Andersen (1997).

One of the earliest approaches, the Uppsala model, suggests that internationalisation activities increase incrementally (Johanson \& Vahlne, 1977; Johanson \& Wiedersheim-Paul, 1975). This process is influenced by increased market knowledge, which leads to increased commitment to international markets and vice versa. According to this model, an organisation follows four stages in the internationalisation process:

- no regular export;

- export via independent enterprises or agents;

- sales subsidiaries;

- establishment of production plants overseas. 
Figure 1: The Internationalisation Theory according to the Uppsala Model

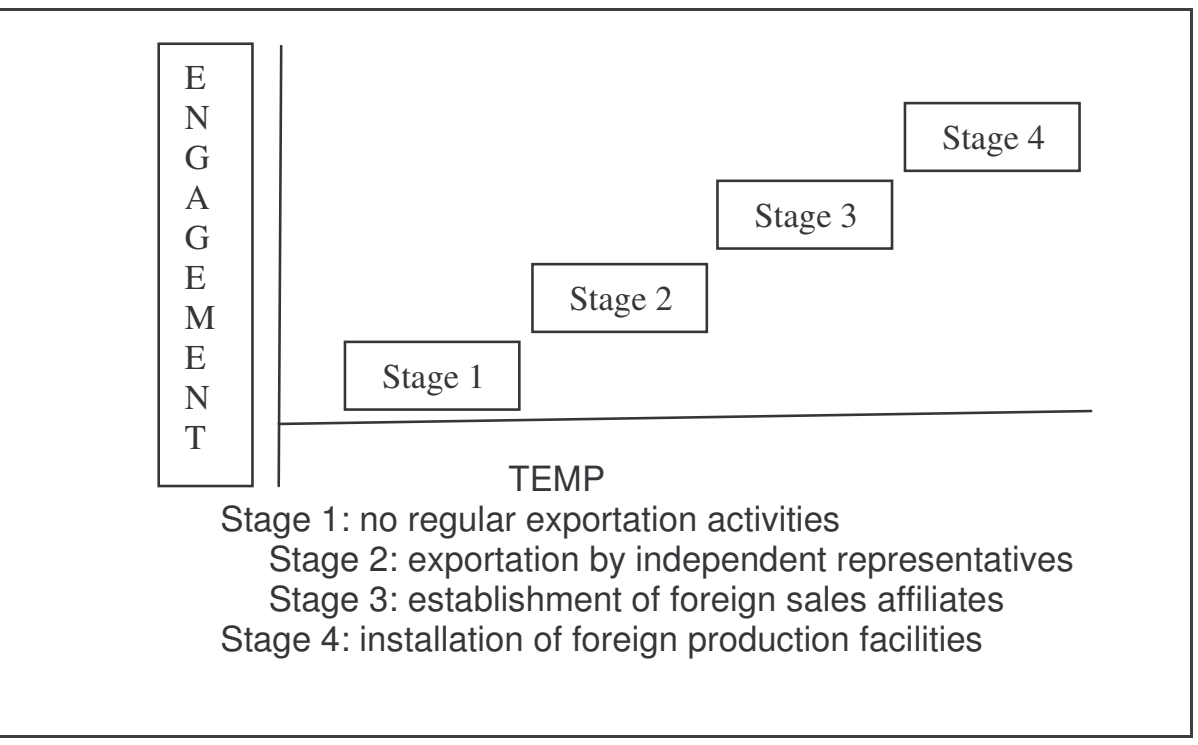

Source: Uppsala model as proposed by Johanson \& Vahlne, 1977; and Johanson \& Wiedersheim-Paul, 1975.

Kuada \& SØrensen (2002), maintain that the existing stages model can be divided into two types:

- Models showing internationalisation to be based on learning and accumulated experience - the Learning Stages Theory.

- Models showing internationalisation to be based on adaptation to changes in the environment the International Product Life Cycle Theory.

According to the Learning Stages theory, the internationalisation of an organisation is an orderly and sequential process in which the shift from one stage to the next is based on learning and the accumulation of experience within the preceding stage. In the International Product Life Cycle Theory, an organisation's internationalisation can be divided into three stages, namely: new product, maturity product, and standardised product.

Another approach draws upon the insights gained by Transaction Cost Analysis (TCA). Transaction costs include the expenses associated with the acquisition of information regarding relevant prices, and the costs entailed in the negotiation and enforcement of contracts. Asset specificity, the frequency of economic exchange, and the level of uncertainty, are the key influences in determining the cost of transacting. Within this context, the decision-maker is boundedly rational and aspires to minimise the cost of transacting associated with entry into the international marketplace. Brouthers \& Nakos (2004) suggest that the transaction cost theory is very useful in explaining SME mode choice and that SMEs that used transaction cost-predicted mode choices performed significantly better than firms using other modes. In addition, the network approach bears considerable similarities with TCA: it draws on theories of social exchange and resource dependency, and focuses on organisational behaviour within interorganisational and interpersonal relationships. Thus, the boundaries of the organisation are determined not only by formal relationships, but also by informal and personalised linkages (Coviello \& McAuley, 1999).

A third approach, the eclectic framework developed by Dunning (1981), embraces elements of the earlier approaches. It suggests that the level and structure of an organisation's international activities will depend on the configuration of particular ownership (organisation-specific assets and skills), location (country- 
specific market potential, investment risk, production costs and infrastructure), and internalisation advantages (the cost of transacting), as well as the extent that the organisation believes that investment in a particular country is consistent with its long-term management objectives and strategy. Lastly, the Organisational Capability approach conceptualises the organisation as a bundle of relatively static and transferable resources, which are then transformed into capabilities through dynamic and interactive organisation-specific processes (Amit \& Shoemaker, 1993).

There is considerable disparity in the ability to exploit opportunities, and confront threats emanating from the internationalisation of economic activity by sizeband. Thus, whereas large organisations and particularly MNCs have had considerable experience of involvement in global markets, the majority of SMEs have only recently adopted an international perspective in their strategies (Bijmolt \& Zwart, 1994; Tesar \& Moini, 1998). More specifically, a growing number of publications drawing upon the experience of SMEs in advanced industrialised countries suggest that these organisations are confronted with greater difficulties in accessing international markets than their large-scale counterparts (Roth, 1992; Smallbone \& Wyer, 1995; Stokes, 1992; Van Horn, 1979). The inability to control prices because of lack of market power, a dependency upon a relatively smaller customer base, and limited (if any) access to policymakers, make the external environment of a small organisation more uncertain than in a large business.

An altogether different set of constraints emanates from the limited resource base of SMEs. Specifically, the financial resources available to a small business can act as a considerable constraint in developing an international orientation. This can take two forms: lack of finance may impede the organisation's ability to identify opportunities arising from the opening-up of national markets; whilst inadequate financial resources may restrict the exploitation of opportunities already identified (Smallbone \& Wyer, 1995).

\section{Capital Structure and Financing of SMEs}

A decision to start a business or expand an existing organisation by increasing the productive assets, involves an implicit decision to raise money capital in order to finance the growth. There are three main sources of funds; namely equity financing, debt financing, and the use of retained earnings. The first two sources of equity and debt financing constitute external financing, while retained earnings are an internal source (Koutsoyiannis, 1982).

The capital structure (or financial structure) of an organisation is a specific mixture of debt and equity the organisation uses to finance its operations. Capital structure decisions are crucial for the survival of any business organisation. Brealey \& Myers (2003) contend that the choice of capital structure is fundamentally a marketing problem. They argue that the organisation can issue dozens of distinct securities in countless combinations but it ultimately attempts to find the particular combination that maximises market value. According to Weston \& Brigham (1990), the optimal capital structure is the one that maximises the price of the organisation's stock. Generally, the theoretical literature for explaining the capital structure of large organisations also applies in the case of SMEs ${ }^{1}$. The finance literature provides three major theories of capital structure: (i) the agency cost/tax shield trade-off model, (ii) the peckingorder hypothesis; and (iii) the signaling model. Megginson (1997) provides a review of these theories with an emphasis on the most researched - the trade-off model. In this model, organisations choose their capital structures by trading off the tax benefits of debt with the agency costs of debt and expected bankruptcy costs.

Certain organisation-level characteristics have been identified in literature to be associated with the financial structure of SMEs. For the purpose of this study, the article provides a review of two of these variables that have been used in previous studies and also discusses capital structure and international activity. These are discussed in turn.

\footnotetext{
${ }^{1}$ The major exception to this being the theories which involve conflicts between owners and management. Basically, SMEs tend to have a less pronounced separation of ownership and management than larger firms
} 


\section{Age of the Organisation}

Age as a determinant of SMEs' financing preference has received little attention. There is little in the literature on this factor. Leeth \& Scott (1989) included age as a measure of risk and reputation in their research. Reputation formation takes time and it provides improved incentives to borrowers. In the absence of reputation, borrowers have incentives to select excessively risky projects. As an organisation ages, it establishes itself as a continuing business and it therefore increases its capacity to take on more debt; hence age is positively related to debt.

Petersen \& Rajan (1994) provided a general model relating the financial structure of a small organisation to its age. The authors suggest that the ownership ratio is high for new organisations. They also assert that older organisations have higher debt ratios since they are seen to be high quality organisations. Barton, Hill \& Sundaram (1989) also argue that mature organisations experience lower earnings volatility and thus are expected to have higher debt ratios. Although maturity is spoken of rather than age, one can intuitively relate maturity to age in a direct fashion. Wedig, Sloan, Hassan \& Morrisey (1988) however concluded that age is negatively related to debt ratio. Diamond (1989) and Esperanca, Ana \& Mohamed (2003) agree with this position by stating that the longer the organisation survives in business, the more internally generated profits it can accumulate that are subsequently used to replace debt financing. Thus its ownership ratio (as in the ratio of shareholders funds to total assets) will be high. Hall, Hutchinson \& Michaelas (2004) also found that age is negatively related to short-term debt but positively related to longterm debt.

\section{Size of the Organisation}

There are several theoretical reasons why organisation size would be related to its capital structure. Firstly, smaller organisations may find it relatively more costly to resolve information asymmetries with formal lenders and financiers. Consequently, smaller organisations are offered less capital, or are offered capital at significantly higher costs than larger organisations.

The transaction costs associated with financing may also affect financing choices as transaction costs are most likely a function of scale, with smaller scale financing resulting in relatively higher transaction costs (Titman \& Wessels, 1988; Wald, 1999). A related issue is the marginal effects of market access for different sized organisations (Scherr, Sugrue \& Ward, 1993). This could be a function of high transaction costs effectively making some financing options outside the available set of financing choices of the organisation. However, market access can also be constrained directly in that some financing options are not in the scale range that formal financiers would consider issuing finance. A simple example is the scale required to obtain equity funds publicly, thereby excluding smaller organisations from this type of finance. According to Titman \& Wessels (1988), another explanation for smaller organisations having lower debt ratios is if the relative bankruptcy costs are an inverse function of organisation size.

Empirical evidence on the relationship between the size and capital structure of organisations is quite varied with respect to conclusions. Several works support a positive relationship between organisation size and leverage (Barclay \& Smith, 1996; Barton et al., 1989; Cassar \& Holmes, 2003; Hall et al., 2004). Their results suggest that smaller organisations are more likely to issue equity while larger organisations are more likely to issue debt rather than stock. Fischer, Heinkel \& Zechner (1989) and Gupta (1969) however found a negative relationship between size and debt ratio. They argued that this result is in accordance with the theoretical model of relevant capital structure choice.

\section{Degree of Internationalisation}

Following from the reasoning of the trade-off model, it is posited that international diversification reduces the expected cost of bankruptcy and allows for increased debt capacity. Other researchers, however, suggested that internationalisation can lead to higher agency costs and a lower level of debt (Lee \& Kwok, 1988). 
Bradley, Jarrel \& Han Kim (1984) suggest that organisations with a higher operating risk should have lower debt, which means that the risk of the organisation's operating cash flows is considered to be a basic capital structure determinant in trade-off models. Shapiro (1978) suggests that an organisation's international diversification is a factor that may be relevant in establishing worldwide capital structures. Fatemi (1988) and Lee \& Kwok (1988) find that MNCs' leverage is lower than DCs' was. Burgman (1996) suggests that specific international factors such as political risk and exchange rate risk are relevant to the multinational capital structure decision.

Prior evidence indicates that MNCs utilise less debt in their capital structures relative to their DC counterparts. Agmon \& Lessard (1977) argue that equity capital is less costly with organisational international activity. Reeb, Kwok \& Baek (1998) reach an opposite conclusion to their counterparts which is attributed to greater exchange rate risks, political risks, and agency costs. The implication is a higher cost of debt financing for international organisations. Lee \& Kwok (1988) compare MNCs and DCs capital structures and find that MNCs have lower debt-to-equity ratios primarily as a result of greater agency costs. Similarly, Burgman (1996), reports that MNCs have a lower target debt-to-equity ratio than pure DCs. His findings suggest that target debt levels for MNCs are determined by a trade-off between the tax advantage of debt and the agency costs of debt.

In addition, Chen, Cheng, He \& Kim (1997) examine the relationship between international activities and capital structure, using a debt-to-equity ratio. Their approach explicitly examines whether there is a direct relationship between organisational internationalisation and debt financing. They find that MNCs have a lower debt ratio than their DCs and that, within MNCs, the level of international activity is positively associated with the debt ratio. They also find, consistent with prior research, that the debt ratio is negatively related to bankruptcy costs and growth options. Similar results for US-based MNCs are also reported in Kwok \& Reeb (2000). In aggregate, these studies suggest greater risk and agency costs with organisational international activity and imply a higher cost of debt capital.

It is therefore postulated that organisational international activity may have different impacts on debtholders based on the level of these activities. This article examines the impact of SMEs' degree of internationalisation on their (capital structure) financing options. The article focuses on NTEs in Ghana because about $97 \%$ of NTEs fall within the category of SMEs (Buatsi, 2002).

\section{METHODOLOGY}

The research focuses on the internationalisation and financing options of small and medium sized exporters drawn from the Ghana Export Promotion Council's (GEPC) database of NTEs in Ghana. A sample of 100 NTEs within the Accra and Tema metropolis was considered for the study. Out of the total of 100 questionnaires, 44 were received from respondents representing a response rate of $44 \%$. Whilst this might not seem a high percentage, empirical studies involving SMEs have been known to generate far lesser percentage response rates.

The study also included age and size effects, two related variables that have been associated with the financial structure of SMEs. The framework used by Feeney \& Riding (1997) and Brewer, Genay, Jackson \& Worthington (1995) was adopted in defining age. Age is defined in terms of infant organisations (those less than one year), young organisations (between one and five years), adult organisations (between five and ten years) and mature organisations (over ten years). The definition of size according to the Regional Project on Enterprise Development's (RPED) classification was used. This is given as: micro enterprise less than 5 employees; small enterprise 6 - 29 employees; medium enterprise 30 - 99 employees; and large enterprise 100 and more employees.

The degree of internationalisation of SMEs can be explained in terms of the growth of export intensity or the foreign sales ratio (i.e. the ratio of export sales to total sales) (Hamilton \& Fox, 1998). This is classified as low export (less than $26 \%)$, moderate export (26\% - 50\%), high export (51\%- $75 \%)$ and intense export (76\% - 100\%). 
The research made use of both primary and secondary data. Secondary data was collected on the capital structure ratios of the organisations from their most recent balance sheets. Capital structure is measured by using the debt ratio (i.e. total debt divided by total assets). Primary data was collected through questionnaire administration. Descriptive statistics were employed in the presentation and analysis of results. The study also made use of non-parametric method in the analysis.

The student's $t$-test for independent samples was used in this study. The t-test determines whether two samples were drawn from populations with different means (Riffe, Lacy \& Fico, 1998:154-162). The t-test deals with the problems associated with inference based on "small" samples: the calculated mean and standard deviation $(\boldsymbol{\sigma})$ may by chance deviate from the "real" mean and standard deviation (i.e. what you would measure if you had many more data items: a "large" sample).

In the case of two samples, it is quite likely that, in detail, the samples are different: different highs, lows, and average sizes. Is the measured difference in average size large enough that we should reject the null hypothesis that, in fact, such differences are due to "chance"? Given the above sort of information on the likely range for the actual mean of each sample, the question basically reduces to whether the likely ranges overlap (in which case the means could be the same in the overlap of the intervals, and we may not reject the null hypothesis) or if they do not overlap (in which case we must reject the null hypothesis: the difference is most likely not due to chance). To report the variety of possible outcomes (from means not "significantly" different to means that are in fact "significantly" different), the probability that the difference is due to chance is reported. Reject the null hypothesis if the probability value is "small".

\section{PRESENTATION OF RESULTS}

This section is devoted to the presentation, analysis and discussion of the empirical results. The results indicate the frequency of debt and equity financing considering organisational characteristics such as age, size and degree of internationalisation.

\section{Table 1: Age of the Firm and Financing Choice}

\begin{tabular}{||llll||}
\hline \hline Capital Structure & Group & Mean & SD \\
\hline Debt & Infant & $0.10^{* \star *}$ & 0.40 \\
& Young & $0.32^{* *}$ & 0.11 \\
& Adult & $0.44^{* * *}$ & 0.15 \\
& Mature & $0.53^{* *}$ & 0.38 \\
\hline
\end{tabular}

${ }^{* \star *}$ significant at $1 \%$

** significant at $5 \%$

*significant at $10 \%$

Table 1 shows how age affects the financing choice of the organisations. Among infant organisations (those less than one year old), $10 \%$ of financing was in the form of debt, while young organisations (between one and five years) reported a debt ratio of $32 \%$. The shares of debt of adult organisations (between six and ten years) and mature organisations (those over ten years) were $44 \%$ and $53 \%$ respectively. The results show that debt financing increases with the age of the organisation. The age effect seems consistent with previous studies (Barton et al., 1989; Petersen \& Rajan, 1994). It is expected that, with time, organisations become more acceptable to lenders, i.e. debt levels will increase causing ownership ratio to fall. Thus, leverage is associated with older organisations. The results show significant mean values. 
Table 2: Size of the Firm and Financing Choice

\begin{tabular}{||llll||}
\hline \hline Capital Structure & Group & Mean & SD \\
\hline Debt & Micro & - & - \\
& Small & $0.46^{* * *}$ & 0.30 \\
& Medium & $0.54^{* * *}$ & 0.26 \\
& Large & $0.64^{* * *}$ & 0.27 \\
\hline
\end{tabular}

*** significant at $1 \%$

${ }^{* *}$ significant at $5 \%$

*significant at $10 \%$

Table 2 reports the relationship between size and financing choice. There were no micro organisations (with an employee size of less than five) in the valid responses. Among small organisations (with between five and twenty nine employees), $46 \%$ of financing was in the form of debt. Fifty four percent (54\%) debt financing was reported for medium-sized organisations (those with employees between thirty and ninety nine). Organisations with over a hundred employees showed $64 \%$ debt financing. The findings provide support for theory (Castanias, 1983; Titman \& Wessels, 1988; Wald, 1999). Larger organisations are more likely to have access to more debt financing than smaller ones. Smaller organisations, apart from being less diversified, find it relatively more costly to resolve information asymmetries with lenders, therefore, may present lower debt ratios. The mean values are significant in the result.

Table 3: Degree of Internationalisation and Financing Choice

\begin{tabular}{||llll||}
\hline Capital Structure & Group & Mean & SD \\
\hline Debt & Low & $0.63^{\text {*** }}$ & 0.19 \\
& Moderate & $0.53^{* * *}$ & 0.34 \\
& High & $0.54^{* *}$ & 0.30 \\
& Intense & 0.57 & 0.46 \\
\hline
\end{tabular}

*** significant at $1 \%$

${ }^{* *}$ significant at $5 \%$

*significant at $10 \%$

The effects of the degree of internationalisation (measured by export intensity) on the organisation's financing options is shown in table 3. Low export organisations (those with export intensity or foreign sales ratios of less than $26 \%$ ) reported $63 \%$ of debt and $37 \%$ of equity financing. Moderate export organisations (those with foreign sales ratios of between $26 \%$ and $50 \%$ ) had a debt ratio of $53 \%$, while high export organisations (those with foreign sales ratios of between $51 \%$ and $75 \%$ ) and intense exporters $(76 \%$ $100 \%$ ) had debt ratios of $54 \%$ and $57 \%$ respectively. The results show that organisations at the earlier stages of internationalisation require more debt to operate. However, the debt ratio falls when the organisation moves from low export level to moderate export level. Moving to high and intense export activities, the debt ratio keeps on increasing. The results generally indicate that the initial stages of internationalisation may require more external funds and that, although the debt ratio may decline, it does again rise with increasing international activities. This seems to suggest that, as organisations engage more in international business, they also employ more debt. Organisations at the initial stage of internationalisation may furthermore be exposed to increased risk whereas, the more organisations become involved in international business, the more diversified they become and are consequently capable of accommodating more debt capital and risk. This position is consistent with the argument that 
international diversification reduces the expected cost of bankruptcy and allows for increased debt capacity. With the exception of the category in Table 3, all the means values are significant.

\section{Table 4: Test Between All Means}

\begin{tabular}{||ll||}
\hline \hline Variable & Test between means \\
\hline Age of the Firm & Infant v Young \\
& Infant v Adult \\
& Infant v Mature \\
& Young v Adult \\
& Young v Mature \\
& Adult v Mature \\
& Small v Medium \\
& Small v Large \\
& Medium v Large \\
\hline Size of the Firm & Low v Moderate \\
& Low v High \\
& Low v Intense \\
& Moderate v High \\
Degree of & Moderate v Intense \\
Internationalisation & Intense v High \\
& \\
& \\
\hline Test & \\
\hline
\end{tabular}

Test Ho mean $(\mathrm{X})$ - mean $(\mathrm{Y})=$ diff. $=0, \mathrm{Ha} \neq 0$

***significant at $1 \%$

${ }^{* *}$ significant at $5 \%$

*significant at $10 \%$

In terms of the test of differences between means (t-test values), the results show a reasonably significant value between young and mature organisations. The test of difference between young and mature organisations suggests that, indeed, the choice of finance could be significantly influenced by how long the organisation stays in business. The results show that debt financing increases with the age of the organisation - signifying that younger organisations depend more on equity finance while mature organisations employ more debt capital.

Though the actual mean values indicate some trend in the capital structure resulting from changes in the organisation-level characteristics (i.e. age, size and degree of internationalisation), caution should be made in generalising these findings considering that the test of differences between means, apart from the difference between young and mature organisations, shows insignificant values.

\section{CONCLUSIONS}

The problem of financing Ghanaian small and medium scale enterprises (SMEs), especially those in the non-traditional export (NTE) sector, has been of great concern for some time now. This pre-occupation is mainly a result of the role the SMEs in the NTE sector are supposed to play in the development of the economy. The article presents a study of internationalisation and the financing options of Ghanaian NTEs. The study exhibited in this article examines how the organisation's degree of internalisation affects the choice of financing. It also incorporates other organisation-level characteristics such as the age and size effects. The results show a positive association between the incidence of using debt and the age of the organisation. Over time, organisations become more acceptable to lenders and therefore, older organisations are more likely to obtain debt financing than younger ones. This effect conforms to standard theories on capital structure choice. In addition, the study indicates that larger organisations are more likely to receive debt financing than their smaller counterparts as a consequence of diversified risk. This appears to support earlier studies. Finally, the study also shows a positive relationship between internationalisation and debt financing at both the low and intense phases of export intensity. The results also suggest that apart from requiring significant financing at the initial stage of internationaliation, 
organisations also employ more debt and less equity financing as they engage more in international activities. This is explained by the fact that organisations involved in international business tend to be more diversified and, as such, are capable of accommodating more debt capital. The actual mean values indicate some trend in the capital structure resulting from changes in the organisation-level characteristics (i.e. age, size and degree of internationalisation). However, caution should be made in generalising these findings considering that the test of differences between means, apart from the difference between young and mature organisations, shows insignificant values.

\section{REFERENCES}

Agmon T \& Lessard B. 1977. Investor Recognition of Corporate International Diversification. The Journal of Finance, 32(4): 1049-1055.

Amit R \& Shoemaker PJH. 1993. Strategic Assets and Organizational Rent. Strategic Management Journal, 14(1): 33-46.

Andersen 0. 1997. Internationalization and Market Entry Mode: A Review of Theories and Conceptual Frameworks. Management International Review, 37: 27-42.

Barclay MJ \& Smith CW Jr. 1996. On financial architecture: Leverage, maturity and priority. Journal of Applied Corporate Finance, 8: 4-17.

Barton SL, Hill NC \& Sundaram S. 1989. An empirical test of stakeholder theory predictions of capital. Financial Management, 18(1): 36-44.

Bradley M, Jarrel GA \& Han Kim E. 1984. On the existence of an optimal capital structure: Theory and evidence. The Journal of Finance, 3: 857-878.

Brealey RA \& Myers SC. 2003. Principles of Corporate Finance, International Edition. New York: Mcgraw Hill.

Brewer B III, Genay H, Jackson WE III \& Worthington PR. 1995. How are small firms financed? Evidence from small business investment companies. Economic Perspectives, Federal Reserve Bank of Chicago, Chicago, IL, November-December: 2-18.

Bijmolt THA \& Zwart PS. 1994. The Impact of Internal Factors on the Export Success of Dutch Small and Medium-Sized Firms. Journal of Small Business Management, 32(2): 69-83.

Brouthers KD \& Nakos G. 2004. SME Entry Mode Choice and Performance: A Transaction Cost Perspective. Entrepreneurship Theory and Practice, 28(3): 1042-2587.

Buatsi SN. 2002. Financing non-traditional exporters in Ghana. The Journal of Business and Industrial Marketing, 17(6): 501-522.

Burgman TA. 1996. An empirical examination of multinational corporate capital structure. Journal of International Business Studies, 27: 553-570.

Calof JL \& Beamish PW. 1995. Adapting to Foreign Markets: Explaining Internationalization. International Business Review, 4(2): 115-131.

Cassar G \& Holmes S. 2003. Capital Structure and Financing of SMEs: Australian Evidence. Journal of Accounting and Finance, 43: 123-147.

Castanias R. 1983. Bankruptcy risk and optimal capital structure. The Journal of Finance, 38: 16171635. 
Chen CJP, Cheng CSA, He J \& Kim J. 1997. An investigation of the relationship between international activities and capital structure. Journal of International Business Studies, 28: 563-577.

Cook P. \& Nixson F. 2000. "Finance and Small and Medium-Sized Enterprise Development". Finance and Development Research Programme Working Paper, No. 14, April.

Coviello NE \& McAuley A. 1999. Internationalization and the Smaller Firm: A Review of Contemporary Empirical Research. Management International Review, 39(3): 223-256.

Diamond DW. 1989. Reputation Acquisition in Debt Markets. Journal of Political Economy, 97(4): 828-62.

Dunning JH. 1981. International Production and the Multinational Enterprise. London: Allen \& Unwin.

Esperanca JP, Ana PMG \& Mohamed AG. 2003. Corporate debt policy of small firms: an empirical (re)examination. Journal of Small Business and Enterprise Development, 10(1): 62-80.

Fatemi AM. 1988. The effect of international diversification on corporate financing policy. Journal of Business Research, 16: 17-30.

Feeney LS \& Riding AL. 1997. Business Owners' Fundamental Tradeoff: Finance and The Vicious Circle of Growth and Control, Canadian Business Owner (November).

Fischer EO, Heinkel R \& Zechner J. 1989. Dynamic capital structure choice: Theory and Test. The Journal of Finance, 44: 19-40.

Gupta MC. 1969. The effect of size, growth, and industry on the financial structure of manufacturing companies. The Journal of Finance, 24: 517-529.

Hall GC, Hutchinson PJ \& Michaelas N. 2004. Determinants of the Capital Structures of European SMEs. Journal of Business Finance and Accounting, 31(5): 0306 - 686X.

Hamilton RT \& Fox MA. 1998. The financing preferences of small firm owners. International Journal of Entrepreneurial Behaviour \& Research, 4(3): 239-248.

Harris M \& Raviv A. 1991. The Theory of Capital Structure. Journal of Finance, 46(1): 297-355.

Johanson J \& VahIne JE. 1977. The Internationalization Process of the Firm-A Model of Knowledge Development and Increasing Foreign Market Commitments. Journal of International Business Studies, 8(1): 23-32.

Johanson J \& Wiedersheim-Paul F. 1975. The Internationalization of the Firm: four Swedish case studies. Journal of Management Studies, 12(3):305-322.

Koutsoyiannis A. 1982. Non Price Decision. The firm in the Modern Context. London: The Macmillan Press Ltd.

Kuada, J \& Sørensen OJ. 2002. Internationalization of Companies from Developing Countries. International Business Press.

Kwok CCY \& Reeb DM. 2000. Internationalization and Firm Risk: An Upstream Dowstream Hypothesis. Journal of International Business Studies, 31(4): 611-629.

Lader P. 1996. The Public/Private Partnership Springs. Spring, 35(2): 41-44. 
Lee KC \& Kwok CCY. 1988. Multinational Corporation Vs Domestic Corporation: International Environment Factors and Determinants of Capital Structure. Journal of International Business Studies, 19(3): 195-217.

Leeth JD \& Scott JA. 1989. The incidence of secured debt: Evidence from the small business community. Journal of Financial and Quantitative Analysis, 24: 379-393.

Megginson WL. 1997. Corporate Finance Theory. Reading MA: Addison-Wesley-Longman, Inc.

Michel A \& Shaked I. 1986. Multinational Corporation Vs Domestic Corporation: Financial Performance and Characteristics. Journal of International Business Studies, 17(4): 89-100.

Myers SC. 1984. The Capital Structure Puzzle. Journal of Finance, 39(3): 575-592.

O'Farrel PN, Wood PA \& Zheng J. 1996. Internationalization of Business Services: An Interregional Analysis. Regional Studies, 30(2): 101-118.

Petersen MA \& Rajan RG. 1994. The Benefits of lending relationships: Evidence from Small Business Data. The Journal of Finance, 49(March): 3-37.

Reeb DM, Kwok CCY \&. Baek YH. 1998. Systematic Risk of the Multinational Corporation. Journal of International Business Studies, 29(2): 263-279.

Riffe D, Lacy A \& Fico FG. 1998. Analysing media messages: using quantitative content analysis in research. Erlbaum Assoc: Mahwah, N.J.

Roth K. 1992. Implementing International Strategy at the Business Unit Level: The Role of Managerial Decision-Making Characteristics. Journal of Management, 18(4): 769-789.

Scherr FC, Sugrue TF \& Ward JB. 1993. Financing the Small Firm Startup: Determining for Debt Use. Journal of Small Business Finance, 3(1): 17-36.

Shapiro AC. 1978. Financial structure and cost of capital in the multinational corporation. Journal of Financial and Quantitative Analysis, 13: 211-226.

Smallbone D \& Wyer P. 1995. Export Activity in SMEs, CEEDR, Working Paper Series, No 9.

Stokes D. 1992. Small Business Management. London: DP Publications.

Tesar G \& Moini AH. 1998. Longitudinal Study of Exporters and Non Exporters: A Focus on Smaller Manufacturing Enterprises. International Business Review, 7: 291-313.

Timmons JA. 1994. New Venture Creation. Chicago: Irwin.

Titman S \& Wessels R. 1988. The Determinants of Capital Structure Choice. Journal of Finance, 43(1): $1-19$.

Van Horn TP. 1979. Strategic Planning in Small and Medium-sized Companies. Long Range Planning, 12: 85-19.

Wald JK. 1999. How Firm Characteristics Affect Capital Structure: An International Comparison. Journal of Financial Research, 22: 161-187.

Wedig G, Sloan FA, Hassan M \& Morrisey MA. 1988. Capital Structure, Ownership, and Capital Payment Policy: The Case of Hospitals. The Journal of Finance, 43(1): 21-40. 
Welch LS \& Luostarinen RK. 1988. Internationalization: Evolution of a Concept. Journal of General Management, 14(2): 34-55.

Weston JF \& Brigham EF. 1990. Essentials of Managerial Finance. The Dryden Press.

Wind Y, Douglas SP \& Perlmutter HV. 1973. Guidelines for Developing International Marketing Strategies. Journal of Marketing, 37(April): 14-23.

Zingales L. 2000. In Search of New Foundation. Journal of Finance, 55: 1623- 1653. 